\title{
BIOEDUSCIENCE
}

ISSN: 2614-1558

https://journal.uhamka.ac.id/index.php/bioeduscience

\section{Identification of Endofit Bacteria in Kawista Leaves (Limonia acidissima L.)}

\author{
Jamiatul Aulia ${ }^{1 *}$, Nining Purwati ${ }^{1}$, Sri Sofiati Umami ${ }^{1}$ \\ ${ }^{1}$ Universitas Islam Negeri Mataram, Jalan Gajahmada, Jempong, Kota Mataram, Indonesia, 83116 \\ *Correspondent Email: liaaulia809@gmail.com
}

\section{ARTICLE INFO}

\section{Article history}

Received: 08 Sept 2020

Accepted: 20 Apr 2021

Published:

\section{Keywords:}

Endofit bacteria

Isolation

Kawista leaves

Limonia acidissima $L$.

\section{A B S T R A C T}

Background: Kawista (Limonia acidissima L.) is a tropical fruit plant that belongs to the Rutaceae tribe. Limonia acidissima L. is widely used traditionally by people in Bima district, West Nusa Tenggara. However, Limonia acidissima L. is not widely known by the public due to the lack of information that studies this plant. This study aims to isolate and identify the bacteria in the leaves of Limonia acidissima L. to obtain in-depth information about the Limonia acidissima L. plant. Methods: The identification process was carried out using a microbiology analyzer with the help of BD Phonix M50 identification tools. The research was conducted at the West Nusa Tenggara Province Health Testing and Calibration Laboratory, using the leaves of Limonia acidissima L. obtained from West Sumbawa Regency. Results: The results showed that a total of eight bacterial isolates from one gram of Limonia acidissima L. leaf were found. Conclusion: Eight types of bacteria found in the leaves of Limonia acidissima L. consist of a group of endophytic bacteria, lactic acid bacteria, metal-reducing bacteria, and pathogenic bacteria. The endophytic bacteria group consists of Bacillus sp. and Bacillus megaterium. The group of lactic acid bacteria, namely Leuconostoc mesenteroides spp. mesenteroides. The metal-reducing bacteria group is Shewanella Putrefaciens while the pathogenic bacteria group consists of Staphylococcus sp., Staphylococcus epidermidis, Staphylococcus capitis and Streptococcus oralis.

Potensi Antibakteria Tanaman Bidara Laut (Ximenia americana) Terhadap Bakteri Vibrio alginolyticus dan V. parahaemolyticus

\section{A B S T R A K}

Background: Kawista (Limonia acidissima L.) merupakan tanaman buah tropis yang termasuk dalam suku jeruk-jerukan (Rutaceae). Limonia acidissima L. banyak dimanfaatkan secara tradisional oleh masyarakat di kabupaten Bima, Nusa Tenggara Barat. Namun Limonia acidissima L. belum banyak diketahui oleh masyarakat luas dikarenakan minimnya informasi yang mengkaji tentang tumbuhan ini. Penelitian ini bertujuan untuk mengisolasi dan mengidentifikasi bakteri yang terdapat pada daun Limonia acidissima L. sebagai salah satu upaya untuk memperoleh informasi yang mendalam tentang tumbuhan Limonia acidissima L. Metode: Proses identifikasi dilakukan secara microbiology analyzer dengan bantuan alat identifikasi BD Phonix M50. Penelitian dilakukan di Balai Laboratorium Kesehatan Pengujian dan Kalibrasi Provinsi Nusa Tenggara Barat, dengan menggunakan daun Limonia acidissima L. yang diperoleh dari Kabupaten Sumbawa Barat. Hasil: Hasil penelitian menunjukkan sejumlah delapan isolat bakteri dari satu gram sampel daun Limonia acidissima L. berhasil ditemukan. Kesimpulan: Jenis bakteri yang ditemukan pada daun Limonia acidissima L. terdiri atas kelompok bakteri endofit, bakteri asam laktat, bakteri pereduksi metal, dan bakteri patogen. Kelompok bakteri endofit terdiri dari Bacillus sp. dan Bacillus megaterium. Kelompok bakteri asam laktat yaitu Leuconostoc mesenteroides spp. mesenteroides. Kelompok bakteri pereduksi metal yaitu Shewanella Putrefaciens sedangkan kelompok bakteri patogen terdiri dari Staphylococcus sp., Staphylococcus epidermidis, Staphylococcus capitis dan Streptococcus oralis.

(c)2021 by authors. License Bioeduscience, UHAMKA, Jakarta. This article is open access distributed under the terms and conditions of a Creative Commons Attribution (CC-BY) license. 


\section{Introduction}

Kawista (Limonia acidissima L.) is a tropical fruit plant that belongs to Rutaceae family. Kawista fruit (is round with thick and complicated skin and has a distinctive aroma (Neelamadhab et al., 2013). Kawista naturally grows in dry areas such as India, Sri Lanka, Myanmar, Indochina, Malaysia, and Indonesia. In Indonesia, this plant grows in coastal areas in Sumatera, Java, Madura, Bali and West Nusa Tenggara (Nurdiana et al., 2016).

In Indonesia, kawista is widely used by people in Bima district, West Nusa Tenggara as processed food and beverages, and traditional medicines to treat various types of diseases. One example of the use of kawista in medicine which has become a habit of the community, is consuming the fruit to treat diarrhea (Nurdiana et al., 2016). Almost all parts of the kawista plant (have the potential to be used as medicine, starting from the seeds, fruits, leaves, and bark (Rodrigues et al., 2018). However, the kawista plant has not been widely cultivated by the public. In addition, this fruit is also less well known because it is rarely consumed, so that it has almost disappeared on the market. This situation is caused by the lack of literature and reading sources that study the kawista plant. This plant has a pretty good prospect for development considering its diverse uses (Vijayakumar et al., 2013).

Bacteria are unicellular prokaryotic microbes that are microscopic and reproduce asexually through cell division. Bacteria can live freely in nature such as in soil, water, human bodies, animals, and plants. The role of bacteria in everyday life can be both beneficial and detrimental. So it's important to study (Pujiati, 2019)

Bacteria in plants can be transient, that is, they live temporarily, or are indigenous, that is, they have settled in several generations (Sumarsih, 2003). One of the factors that attract organisms to live in this environment is related to primary productivity which can provide food for the survival of the associated organisms. Association of plants with microorganisms can occur on plant surfaces (epiphytes) and can also be in plant tissue (endophytes) (Julianawita, C. J. K., \& Idris).

Different habitat provides a different diversity. In plants, the habitat that is often inhabited by bacteria is the leaves. Each plant has different leaves, both in terms of shape, size, and the exudate it releases. This difference causes the bacteria that inhabit it to be different, although in certain plants the same population of bacteria is found (Jumardin et al., 2018).

The very wide diversity of bacteria can be studied through the process of bacterial identification morphologically, physiologically, and molecularly. The stages before the identification process can be started by looking at the relationship between bacterial isolates using a similarity level. The similarity of bacteria can be determined using the characters of colony morphology and bacterial cell morphology. So that these characters can be used to group certain bacteria (Anggara et al., 2014). In this regard, this study aims to isolate and identify the endophytic bacteria found in kawista leaves as an effort to obtain in-depth information about the kawista plant.

\section{Materials and Methods}

\section{Research Design}

This research is a qualitative descriptive study with experimental laboratory methods. Kawista leaves were obtained from the West Sumbawa district. The leaves of Limonia acidissima $L$. used are dark green leaves taken at the base of the lower trunk of a tree branch and randomly selected. This research was conducted from September to October 2019 at the Health Testing and Calibration Laboratory Centre, West Nusa Tenggara.

\section{Tools and Materials}

The tools and materials used in this study were masks, gloves, Erlenmeyer $500 \mathrm{ml}$ (Iwaki), measuring cups $100 \mathrm{ml}$ (Pyrex), test tubes (Pyrex), reaction tube racks (Globolab), drop pipettes (Pyrex), measuring pipettes $10 \mathrm{ml}$ (Pyrex), ball pipette (D\&N), stirring rod (Pyrex), mortar, pestle, 100x20 petri dish (Normax), spreader (Pyrex), ose needle, tweezers, bunsen, plastic wrap, aluminium foil, cotton, gauze, refrigerator, analytical scale (Mettler Toledo), incubator (Binder), oven (Memmert), laminar airflow, autoclave (All American), micropipette (Joanlab), BD Phonix M50 instrument, BD Phonix panels, BD Phonix ID reagents, BD PhonixSpec nephelometer, BD Phonix system accessories, 1 gram of kawista leaves, sterile distilled water, $70 \%$ ethanol, $2 \% \mathrm{NaOCl}$, NA medium (Sodium Agar).

\section{Research Procedure}

\section{Sample Surface Sterilization}

Kawista leaves were weighed as much as 1 gram, then washed with running water until clean. The first sterilization process is by immersing the leaf in $70 \%$ ethanol solution for 1 minute. The second sterilization is soaking it in $2 \%$ sodium hypochlorite ( $\mathrm{NaOCI}$ ) solution for 2 minutes. The third sterilization was followed by soaking it again in $70 \%$ ethanol solution for 30 seconds. Finally, the leaves are rinsed with sterile distilled water up to 10 times.

\section{Isolation of Bacteria}

Isolation of bacteria was carried out using the spread plate method, with a sample dilution of up to 10-3. Then as much as $100 \mu \mathrm{l}$ was taken from each dilution, which was then spread on the surface of the NA media using a spreader and incubated for 72 hours at $35^{\circ} \mathrm{C}$. Furthermore, observations are made every day to see any growing colonies. Bacterial isolates that grew on each medium were identified based on differences in colony morphology 
(shape, surface, edge, elevation, and color) then transferred to sloping NA media to be stored as stock.

\section{Bacterial Staining}

A total of one bacterial loop was taken aseptically and suspended with distilled water on the slide. Then the preparations were fixed over a bunsen fire until dry. The preparations were dripped with a crystal violet solution, let stand for 1 minute, and then rinsed with running water and dried. The preparations were dripped with iodine solution, let stand for 1 minute, and then rinsed with running water and dried. The preparation is leaked with 96\% alcohol solution until the purple color disappears. The preparation is dripped with safranin solution and allowed to stand for 30 seconds, then rinsed with running water and dried Emersion oil on the preparations and observed under a microscope. The gram test is positive if it is purple and negative if it is red.

\section{Identification of Bacteria Isolates}

A total of 8 plates containing pure cultures of bacteria were characterized by colony morphology by observing colony shape, colony surface, colony edge, colony color, and gram stain. Furthermore, regarding the morphology of bacterial cells by carrying out the bacterial gram staining process. After obtaining the results of colony morphological characterization and bacterial cells, it was continued with the identification process of bacteria using a microbiology analyzer called the BD Phonix M50 tool.

\section{Microbiology Analyzer}

The identity of each kawista leaf sample (Limonia acidissima L.) was inputted into the provided computer program. Furthermore, the panels and reagent IDs were labeled based on the gram type of bacteria. One loop of pure culture isolate on slant NA (Sodium Agar) medium was taken and suspended into the ID reagent solution. The solution was then homogenized, and then the turbidity level was measured in the range of 0.4-0.6 using a Nephelometer. If the turbidity standard has been met, the solution is put into the panels. Furthermore, the panels are inserted into the BD Phonix M50 identification tool. The workflow of a microbiology analyzer using the BD Phonix M50 tool is presented in Figure 1.

\section{Data Analysis}

Data obtained from the microbiology analyzer in the form of bacterial species names were analyzed descriptively qualitatively by tabulating each of the morphological characteristics of the bacterial colony (shape, surface, edge, elevation, color), a gram of bacteria with the species name found.
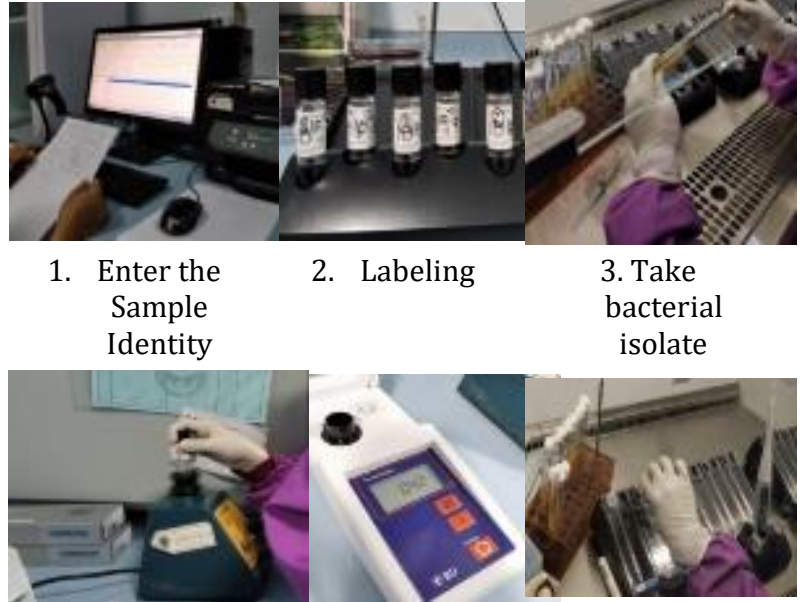

4. Homogenizing the solution

5. Measuring the level of turbidity

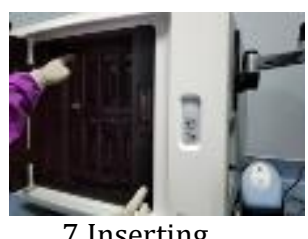

7.Inserting

panels into the BD

Phonix M50 tool

Figure 1. Microbiology Analyzer Workflow

\section{Result}

\section{Morphology of Bacteria on Kawista Leaves (Limonia acidissima $L$.)}

Based on the study results, there were eight bacterial isolates from Limonia acidissima L. that were successfully obtained. The observation process was carried out by first characterizing the morphological colony of kawista leaf bacteria. The results showed that the bacteria found had colonies with round and irregular shapes. Colony surface smooth and rough, with flat and wavy edges. Colony elevation or height is flat, raised, and convex, with colony colors, namely white, yellowish-white and yellow.

The results of the gram test show there are seven grampositive bacteria isolates, and one gram-negative bacteria isolate. The results of the characterization of bacteria found are presented in Table 1. 
Table 1. Morphological Characteristics of Bacteria on Kawista Leaves (Limonia acidissima L.)

\begin{tabular}{|c|c|c|c|c|c|c|}
\hline \multirow{2}{*}{ Isolate Code } & \multicolumn{5}{|c|}{ Morphology } & \multirow{2}{*}{ Gram } \\
\hline & Shape & Surface & Edge & Elevation & Color & \\
\hline KWS 1.1 & Irregular & Rough & Wavy & Flat & White & + \\
\hline KWS 1.2 & Round & Smooth & Align & Convex & Yellowish white & + \\
\hline KWS 1.3 & Round & Smooth & Align & Arise & Yellowish white & + \\
\hline KWS 2.1 & Round & Smooth & Align & Flat & Yellowish white & + \\
\hline KWS 2.2 & Round & Smooth & Align & Flat & White & + \\
\hline KWS 2.3 & Round & Smooth & Align & Arise & White & + \\
\hline KWS 3.1 & Round & Smooth & Align & Convex & White & + \\
\hline KWS 3.2 & Round & Smooth & Align & Convex & Yellow & - \\
\hline
\end{tabular}

\section{Identification of Bacteria Types}

Before identifying the bacterial species, the gram stain process is carried out first. Gram staining is one way to determine the nature of bacteria belonging to grampositive or gram-negative so that further data can be used as a data specification to identify bacteria with the microbiology analyzer method using the BD Phonix M50 tool.

The results of gram staining showed that there were 7 gram-positive bacteria and 1 gram-negative bacteria. The results of bacterial identification obtained were 8 bacteria. Details about the gram of bacteria found are presented in Table 2

A total of 8 growing bacterial isolates were obtained from $10-1$ to $10-3$ dilutions. $10-1$ dilution in repetition medium (1, 2, and 3), 10-2 dilution on repetition medium $(1,2$, and 3$)$, and 10-3 dilution on replication medium (1 and 2) so that 9 replications were obtained on 3 times of dilution. Complete identification results of bacteria on kawista leaves are presented in Table 3.

Table 2. Image of Gram Staining Results for Bacteria on Kawista Leaves

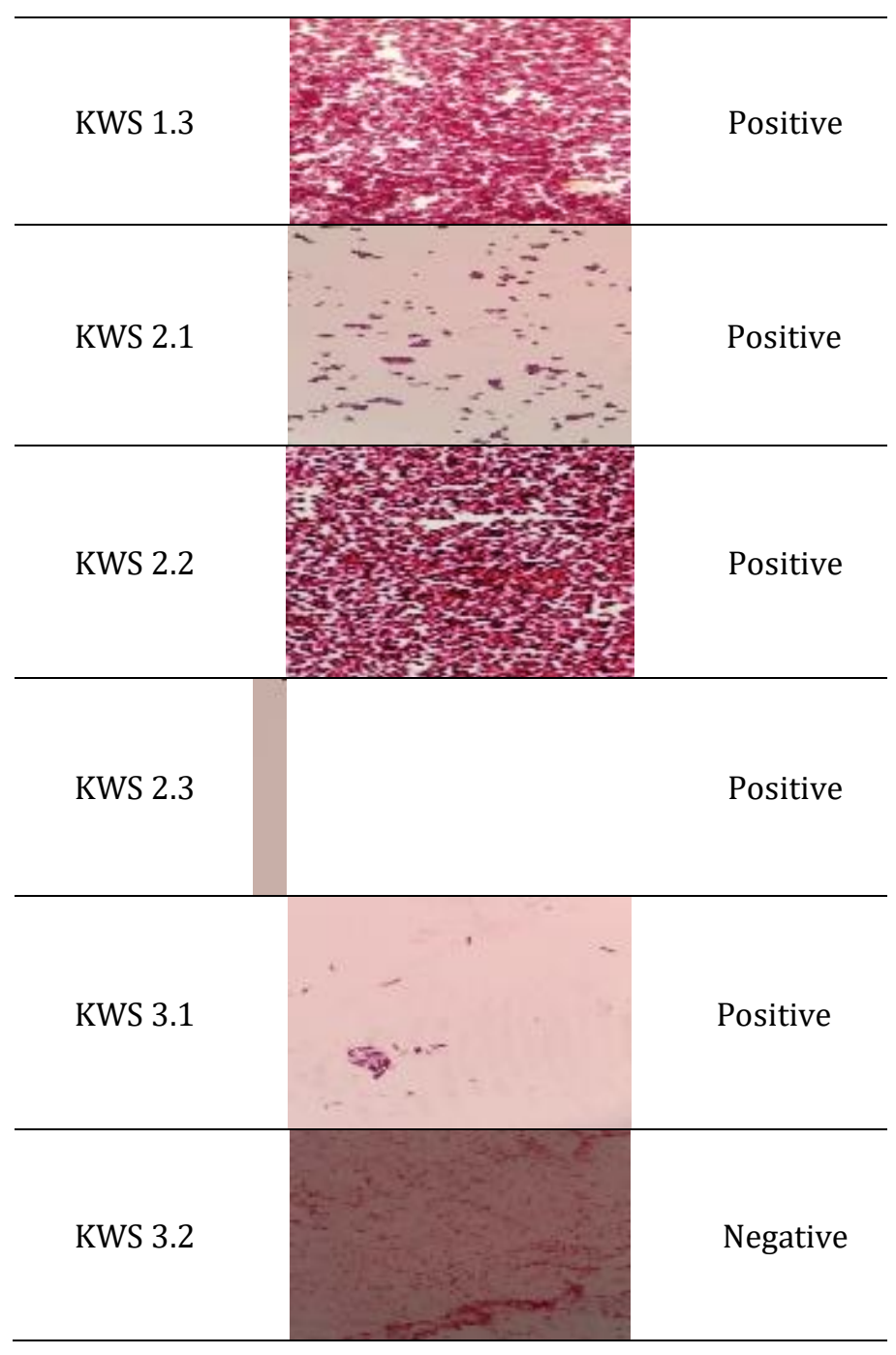

\section{Isolate Code Image of Gram Staining Gram}

KWS $1.1 \quad$ Positive


Table 3. Results of Bacterial Identification on Kawista Leaves

\begin{tabular}{cl}
\hline Isolate Code & \multicolumn{1}{c}{ Species } \\
\hline KWS 1.1 & Bacillus sp. \\
KWS 1.2 & Bacillus megaterium \\
KWS 1.3 & Staphylococcus sp. \\
KWS 2.1 & Staphylococcus epidermidis \\
KWS 2.2 & Staphylococcus capitis \\
KWS 2.3 & Streptococcus oralis \\
KWS 3.1 & Leuconostoc mesenteroides spp. \\
KWS 3.2 & mesenteroides \\
\hline
\end{tabular}

\section{Discussion}

The results showed that there were eight types of bacteria on kawista leaves that came from different groups. These bacterial groups are endophytic bacteria, Lactic Acid Bacteria (LAB), metal-reducing bacteria, and pathogenic bacteria. The endophytic group of bacteria found consists of Bacillus sp. and Bacillus megaterium. The lactic acid bacteria group, namely Leuconostoc mesenteroides spp. mesenteroides. Metal reducing bacteria group namely Shewanella putrefaciens, whereas the pathogenic bacteria group consists of Staphylococcus sp., Staphylococcus epidermidis, Staphylococcus capitis dan Streptococcus oralis.

Endophytic bacteria live in the internal tissues of plants by forming colonies without causing adverse effects on their host plants (Tangapo et al., 2018). Endophytic bacteria can live in vascular vessels or the intercellular space, roots, stems, leaves, seeds and fruit (Abedinzadeh et al., 2019). The mechanism of invasion of endophytic bacteria into plant tissue can occur in several ways; namely, bacteria can enter through stomata, lenticels, natural wounds, lateral root growth points, growing radicles, and undesirable meristematic root tissue. Differentiable (Santoyo et al., 2016).

The existence of endophytic bacteria in a plant is of important value because endophytic bacteria can produce potential products (bioactive compounds) that are similar to their host plants. The resulting compounds are beneficial for the plants themselves and can be useful in various aspects of life, such as in agriculture, the environment, industry, and health (Knoess \& Wiesner, 2019).

The endophytic bacteria found on kawista leaves are Bacillus sp. and Bacillus megaterium. Bacillus sp. known to be able to suppress the number of pathogens and increase growth in plants (Mary et al., 2014). Furthermore Puspita et al., (2019) that Bacillus sp. also able to produce IAA (Indole Acetic Acid) or plant growth hormone to increase plant growth through the addition of a better number of colonies.

Bacillus megaterium is useful as a nematode biocontrol agent in plants. Mekete et al., (2009), reported that Bacillus megaterium is known to reduce the number of nematode eggs that cause branching tuber disease in plants, namely Meloidegyne incognita. Apart from being a nematode biocontrol agent, López-Bucio et al. (2007) suggested that the Bacillus megaterium could also increase plant growth and development, namely Phaseolus vulgaris and Arabidopsis thaliana.

Lactic acid bacteria can be found in plants, dairy products, meat, and various fermentation products. LAB is a group of bacteria widely used as bio preservatives to suppress and eliminate pathogenic and putrefactive bacteria in food (Kusumawati, 2012). According to Laily et al. (2013), Leuconostoc mesenteroides spp. is one of the bacteria belonging to the lactic acid bacteria commonly used as the fermentation of food ingredients.

Metal reducing bacteria are widely used for bioremediation of environmental or cleaning of pollutants such as chlorinated compounds, radionuclides, and other environmental pollutants (Venkateswaran et al., 1999). One of the bacteria belonging to the metal-reducing group found in kawista leaves is Shewanella putrefaciens. This bacterium is an anaerobic, facultative bacteria that can reduce iron and metabolic manganese as an electron acceptor terminal in the electron transport chain (Khashe \& Michael, 1998).

Pathogenic bacteria are bacteria that harm plants by causing damage and symptoms typical of plants. Generally, pathogenic bacteria can live parasitically (pathogenic) in plant tissue, epiphytic on the surface of plant parts such as shoots, leaves, stems, flowers, fruit, stems, branches, twigs, and roots or can also live and develop by taking nutrients from the host plant and causes damage to the host plant (Winarni, 2013). This is very different from endophytic bacteria, which, although using nutrients from the host plant, does not cause damage and even contributes to plant resistance to pathogens and environmental conditions (Tangapo et al., 2018)

The group of pathogenic bacteria found in kawista leaves consists of Staphylococcus sp. (Fatoba et al., 2014), Staphylococcus epidermidis (Namvar et al., 2014) Staphylococcus capitis (Greco-Stewart et al., 2013), and Streptococcus oralis (Johnsborg et al., 2008).

The various species of bacteria found indicated the diversity of bacteria Limonia acidissima L.. The bacteria found are bacteria that come from the environment and invade plant tissue in several ways, one of which is through the stomata on the leaf surface (Anjum \& Chandra, 2015), so that it allows for a diversity of bacteria found in kawista. This is reinforced by Zinniel, Lambrecht, Harris, Kuczmarski, et al. (2002) that bacteria in a plant are not limited to one bacterial species but consist of several genera and species.

The existence of various bacteria found in kawista leaves in this study can be the basis for efforts to increase the prospect of using kawista plants. One of them is by carrying out the process of molecular identification of bacteria so that better results can be obtained. 


\section{Conclusion}

Eight bacterial isolates were found on Limonia acidissima L. leaves obtained from three dilutions and nine replications. The bacteria found consisted of endophytic bacteria, lactic acid bacteria, metal-reducing bacteria, and pathogenic bacteria. The endophytic bacteria group consists of Bacillus sp. and Bacillus megaterium. The group of lactic acid bacteria (LAB), namely Leuconostoc mesenteroides spp. mesenteroides. The metal-reducing bacteria group is Shewanella putrefaciens, while the pathogenic bacteria group consists of Staphylococcus sp., Staphylococcus epidermidis, Staphylococcus capitis dan Streptococcus oralis.

\section{Declaration statement}

The authors reported no potential conflict of interest.

\section{Reference}

Abedinzadeh, M., Etesami, H., \& Alikhani, H. A. (2019) Characterization of Rhizosphere and Endophytic Bacteria from Roots of Maize (Zea mays L.) Plant Irrigated with Wastewater with Biotechnological Potential in Agriculture. Biotechnology Reports, 21(2018), e00305. Doi: 10.1016/j.btre.2019.e00305

Anggara, B. S., Yuliani, Y., \& Lisdiana, L. (2014). Isolasi dan Karakterisasi Bakteri Endofit Penghasil Hormone Indole Acetic Acid Dari Akar Tanaman Ubi Jalar, [Isolation and Characterization of Endophytic Bacteria Producing Indole Acetic Acid Hormone From Sweet Potato Roots]. LenteraBio, 3(3).

Anjum, N., \& Chandra, R. (2015). Endophytic Bacteria: Optimization of Isolation Procedure from Various Medicinal Plants and Their Preliminary Characterization. Asian Journal of Pharmaceutical and Clinical Research, 8(4), 233-238.

Fatoba, O. S., Esezobor, D. E., Akanji, O. L., Fatoba, A. J., Macgregor, D., \& Etubor, J. (2014). The Study of the Antimicrobial Properties of Selected Engineering Materials' Surfaces. Journal of Minerals and Materials Characterization and Engineering, 02(02), 78-87. Doi: 10.4236/jmmce.2014.22012

Greco-Stewart, V. S., Ali, H., Kumaran, D., Kalab, M., Rood, I. G. H., de Korte, D., \& Ramírez-Arcos, S. (2013). Biofilm Formation by Staphylococcus capitis Strains Isolated from Contaminated Platelet Concentrates. Journal of Medical Microbiology, 62(7), 1051-1059. Doi: 10.1099/jmm.0.050500-0

Johnsborg, O., Eldholm, V., Bjørnstad, M. L., \& Håvarstein, L. S. (2008). A Predatory Mechanism Dramatically Increases the Efficiency of Lateral Gene Transfer in Streptococcus pneumoniae and Related Commensal Species. Molecular Microbiology, 69(1), 245-253. Doi: 10.1111/j.13652958.2008.06288.x

Julianawita, C. J. K., \& Idris, F. (n.d.). Karakteristik Bakteri Epifit dan Endofit yang Berasosiasi pada Daun Lamun Enhalus acoroides.

Jumardin, J., Fathurrahman, F., Kadekoh, I., \& Ete, A. (2018). Eksplorasi Mikroba Epifit, Endofit dan Rizosfer dari Berbagai Sumber Padi Gogo di Kecamatan Kulawi Kabupaten Sigi, [Exploration of Epiphytic, Endophytic and
Rhizosphere Microbes from Various Sources of Upland Rice in Kulawi District, Sigi Regency]. Jurnal Agrotech, 8(2), 73-78. Doi: 10.31970/agrotech.v8i2.22

Khashe, S., \& Michael Janda, J. (1998). Biochemical and pathogenic properties of Shewanella alga and Shewanella putrefaciens. Journal of Clinical Microbiology, 36(3), 783787. Doi: $10.1128 / j \mathrm{jm} .36 .3 .783-787.1998$

Knoess, W., \& Wiesner, J. (2019). The Globalization of Traditional Medicines: Perspectives Related to the European Union Regulatory Environment. Engineering, 5(1), 22-31. Doi: 10.1016/j.eng.2018.11.012

Kusumawati, N. (2012). Peranan Bakteri Asam Laktat dalam Menghambat Listeria monocytogenes pada Bahan Pangan, [The Role of Lactic Acid Bacteria in Inhibiting Listeria monocytogenes in Food Materials]. Jurnal Teknologi Pangan Dan Gizi, 1(1), 14-28. Doi: 10.33508/JTPG.V1I1.77

Laily, I. N., Utami, R., \& Widowati, E. (2013). Isolasi dan Karakterisasi Bakteri Asam Laktat Penghasil Riboflavin dari Produk Fermentasi Sawi Asin, [Isolation and Characterization of Riboflavin Producing Lactic Acid Bacteria from Salted Mustard Fermentation Products]. Jurnal Aplikasi Teknologi Pangan, 2(4).

López-Bucio, J., Campos-Cuevas, J. C., Hernández-Calderón, E., Velásquez-Becerra, C., Farías-Rodríguez, R., MacíasRodríguez, L. I., \& Valencia-Cantero, E. (2007). Bacillus megaterium Rhizobacteria Promote Growth and Alter rootsystem Architecture through an Auxin- and Ethyleneindependent Signaling Mechanism in Arabidopsis thaliana. Molecular Plant-Microbe Interactions, 20(2), 207-217. Doi: 10.1094/MPMI-20-2-0207

Mary, F., Nongkhlaw, W., \& Joshi, S. R. (2014). Epiphytic and Endophytic Bacteria that Promote Growth of Ethnomedicinal Plants in The Subtropical Forests of Meghalaya, India. Revista de Biología Tropical, 62 (December), 1295-1308.

Mekete, T., Hallmann, J., Kiewnick, S., \& Sikora, R. (2009) Endophytic bacteria from Ethiopian coffee plants and their potential to antagonize meloidogyne incognita. Nematology, 11(1), 117-127. Doi: $10.1163 / 156854108 \times 398462$

Namvar, A. E., Bastarahang, S., Abbasi, N., Ghehi, G. S., Farhadbakhtiarian, S., Arezi, P., Hosseini, M., Baravati, S. Z., Jokar, Z., \& Chermahin, S. G. (2014). Clinical characteristics of Staphylococcus epidermidis: a systematic review. GMS Hygiene and Infection Control, 9(3), Doi: $10.3205 /$ dgkh000243

Neelamadhab, P., Patro, V. J., Jena, B. K., \& Panda, P. K. (2013). Evaluation of Phytochemical and Anti-Microbial Activity of Ethanolic Extract of Limonia acidissima L. Leaves. International Journal of Herbal Medicine, 1(1), 22-27.

Nurdiana, Z., Hartana, A., \& Ariyanti, N. S. (2016). Variasi Morfologi dan Pengelompokan Kawista (Limonia acidissima L.) di Jawa dan Kepulauan Sunda Kecil, [Morphological Variations and Groupings of Kawista (Limonia acidissima L.) in Java and the Lesser Sunda Islands]. Floribunda, 5(4), 144-156. Doi: 10.1007/978-94007-4053-2_101

Pujiati, P. (2019). Buku Aja Mikrobiologi Umum.

Puspita, F., Saputra, S. I., \& Merini, D. J. (2019). Uji Beberapa Konsentrasi Bakteri Bacillus sp. Endofit untuk Meningkatkan Pertumbuhan Bibit Kakao (Theobroma cacao L.), [Test of several concentrations of Bacillus $s p$. 
Endophytes to Increase Growth of Cocoa (Theobroma cacao L.) Seeds]. Jurnal Agronomi Indonesia (Indonesian Journal of Agronomy), 46(3), 322-327. Doi: 10.24831/jai.v46i3.16342

Rodrigues, S., Brito, E. S. de, \& Silva, E. de O. (2018). Wood AppleLimonia acidissima. In Exotic Fruits. Elsevier Inc. Doi: 10.1016/b978-0-12-803138-4.00060-5

Santoyo, G., Moreno-Hagelsieb, G., del Carmen Orozco-Mosqueda, M., \& Glick, B. R. (2016). Plant growth-promoting bacterial endophytes. Microbiological Research, 183, 92-99. Doi: 10.1016/j.micres.2015.11.008

Sumarsih, S. (2003). Mikrobiologi Dasar. Fakultas Pertanian UPN "Veteran" Yogyakarta. doi: 10.1148/77.1.94

Tangapo, A. M., Astuti, D. I., \& Aditiawati, P. (2018). Dynamics and Diversity of Cultivable Rhizospheric and Endophytic Bacteria During The Growth Stages of Cilembu Sweet Potato (Ipomoea batatas L. var. cilembu). Agriculture and Natural Resources, 52(4), 309-316. Doi: 10.1016/j.anres.2018.10.003

Venkateswaran, K., Dollhopf, M. E., Lies, D. P., Saffarini, D. A., Gregor, B. J. M., White, D. C., Ni, M., Ri, D. B., Stackebrandp, E., Nealsonl, K. H., \& Shewanella, K. (1999). Polyphasic Taxonomy of the Genus Shewanella and Description of Shewanella oneidensis sp. nov. International Journal of Systematic Bacteriology, 49(2), 705-724.

Vijayakumar, P., Punitha, K., \& Banupriya, L. (2013). Drying Characteristics and Quality Evaluation of Wood Apple (Limonia Acidissima L.) Fruit Pulp Powder. International Journal of Current Trends in Research, 2(1), 147-150.

Winarni, I. (2013). Isolasi dan Karakterisasi Bakteri Patogen Pada Benih Padi dan Kedelai, [Isolation and Characterization of Pathogenic Bacteria in Rice and Soybean Seeds]. Jurnal Matematika, Sains, Dan Teknologi, 14(2), 135-141.

Zinniel, D. K., Lambrecht, P., Harris, N. B., Kuczmarski, D., Higley, P., Ishimaru, C. A., Arunakumari, A., Barletta, R. G., Vidaver, A. K., Zinniel, D. K., Lambrecht, P., Harris, N. B., Feng, Z., Kuczmarski, D., Higley, P., Ishimaru, C. A., Arunakumari, A., Barletta, R. G., \& Vidaver, A. K. (2002). Isolation and Characterization of Endophytic Colonizing Bacteria from Agronomic Crops and Prairie Plants. Applied and Environmental Microbiology, 68(5), 2198-2208. Doi: 10.1128/AEM.68.5.2198 